\title{
Implementation of Cooperative Learning Model on E-Assignment Responsiveness at Higher Education
}

\author{
https://doi.org/10.3991/ijet.v14i18.10752
}

\author{
Sri Restu Ningsih ${ }^{(\varpi)}$, Z. Mawardi Effendi, Nurhasan Syah \\ STMIK Indonesia Padang, Padang State University, Indonesia \\ srirestuningsihestmikindonesia.ac.id
}

\begin{abstract}
Nowadays, there are still many universities that have not maximized the use of information technology in the learning process. The learning process still uses conventional methods, especially in terms of student assignments. The purpose of this study was to develop cooperative learning models in information systems project management courses. The method used in this study was the ADDIE model (Analysis, Design, Development, Implementation, and Evaluation). This is one model that becomes a guideline in developing effective, dynamic learning and supporting learning itself. The results of this study are practical and effective web-based cooperative learning models for students in universities.
\end{abstract}

Keywords - Cooperative learning, ADDIE, web-based

\section{Introduction}

At this time, in an era of increasing technological knowledge and information, people are experiencing an increase in technological change and development, all leading to global integration which is driving huge demands for change, especially in the field of education [1]. Along with the development of information technology and computer technology, human-computer interaction technology was gradually developed to combine more than two types of technology [2].

The learning model is a pattern that is always used as a guide in classroom learning and tutorials for lecturers at universities. The learning model must refer to the approach that will be used, including learning objectives, environment and management classroom. The lecturer learning model can help students get information, ideas, skills, ways of thinking and expressing ideas, also serves as a guide for learning designers. The learning model can also be said as a procedure or steps that educators need to do to facilitate active, participatory and interactive learning for students, with the aim of achieving educational goals, namely the optimal development of student self-potential. Conventional learning methods remain inadequate to this day and students must be responsible for their own learning process, while the teacher only functions as a guide for students [3]. The teaching method implemented in its use for online learning runs in parallel with the development of models and methods that 
enrich data by analyzing it and thereby contributing to the optimization of the learning process [4]. The overall architecture of the data centre is inspired by software [5].

Previous research suggests that in the world of education, cooperative learning has had a long history since time immemorial; the lecturers have encouraged their students to work together in certain group assignments in discussions, debates, or additional lessons [6]. Conventional learning does not train students to interact and be skilled in using computers. As a result, students do not gain valuable expertise in the field of computers as a provision in the future [7].

E-learning collects two main fields, namely learning and technology. Learning is a cognitive process for achieving knowledge, and technology is the medium of the learning process, which means that technology is used like other tools on the Internet. The websites must be supported by computer networks through the implementation of clients on the internet network. As the development of computer technology is increasingly rapid and penetration in many fields has made developments in the management of education in universities [8].

This study makes a Cooperative Learning model in E-Assignment Responsive (CLEAR), which is a model of web-based cooperative learning in making assignments given by lecturers. Besides that students are also introduced to the learning process electronically or web-based learning. Here students are divided into several groups who will later have to do the assignments given by the Lecturer. Tasks that are usually paper-based will change the paradigm to a web-based task that will be given to lecturers through online media. This model can improve the quality of learning for students and can be used as an alternative for the development of a more effective and efficient education system with lower costs in the future.

\section{Literature Review}

Researches that are relevant to the development of cooperative learning models conducted are those presented by Van Dat Tran (2014) Faculty of Education, An Giang University, Vietnam, with the title The Effects of Cooperative Learning on the Academic Achievement and Knowledge Retention. This study is about the effect of cooperative learning on academic achievement and knowledge retention of students. The study was conducted on 110 students at Giang University. Students were divided into two groups, namely the cooperative learning experimental group employed and the lecture-based control group. The results showed that after eight weeks, instructed to use cooperative learning achieved much higher scores on achievement and retention knowledge than in the teaching-based control group [9].

Research from Lim Hooi Leng, Chin Hai Leng, Nabeel Abedalaziz (2015) with the title Using In Cooperative Learning To Improve The Achievement of History Learning. This study uses a Cooperative Learning Weblog to improve students' learning history. The problem of this study is the lack of interest and the low value of student achievement. The research objective is the incorporation of Weblogs in Cooperative Learning in Historical teaching and learning activities, and measuring the effectiveness of Weblogs of Cooperative Learning in improving students' learning abilities. 
The results of the study show that using Weblogs in Cooperative Learning can improve History learning by using the blended learning environment and Wordpress as its learning platform. In this case, Cooperative learning is used as a method of teaching and learning [10].

Research by Umit Yapici (2016) with the title Effectiveness of Blended Cooperative Learning Environment in Biology Teaching: Classroom Community Sense, Academic Achievement and Satisfaction. The purpose of this study is to examine the effect of Blended Cooperative in learning environments Creative (BCLE) in biology subjects, as well as on academic achievement and student satisfaction levels. This research uses quantitative and qualitative research methods together. The study was conducted with 30 students in the 2012-2013 school years and with 31 students in the field of acceleration in 2013-2014 by taking "Seed of Systematic Plants" in the Department of Biology Education at a University in Turkey. The results of this study reveal that the class community of students is developing and they can improve academic achievement and have a high level of satisfaction in learning [11].

\section{$3 \quad$ Method}

One model for designing learning is the ADDIE model. The ADDIE model, which stands for Analysis, Design, Development, Implementation, Evaluation, is one of the models that guide the development of effective, dynamic learning and supports learning itself. The ADDIE model is a system-oriented general learning design model.

The development of the ADDIE model consists of 5 steps of development, namely:

- Analysis: At this stage identification of learning problems, curriculum and learning objectives need analysis of students and instructors, existing knowledge and various other things related to learning.

- Design: This stage will be verified from problem-solving and designing learning models in an effort to solve the problems that have been set.

- Development: At this stage of development, it produces and validates learning products. This process is quite complicated because it relates to the preparation and development of research products which are important factors in improving the quality of the learning model developed so that at this stage complex competencies are also needed.

- Implementation: At this stage, it is done by preparing a learning environment in accordance with the learning model developed. The final results of this stage are to find out the practicality and effectiveness of the web-based CLEAR learning model.

- Evaluation: At this evaluation stage, the process of assessing the quality of development products before or after the implementation of the CLEAR learning model is developed, whether there are still weaknesses or shortcomings that need to be corrected. The evaluation phase is directed to gather information about how successful the model can work in achieving the learning objectives that have been formulated. 


\subsection{Data analysis}

In the table below can be seen the phenomenon of several learning process variables used by lecturers and what is expected by students and lecturers in the learning process.

Table 1. The phenomenon in learning Project Management Information System subject

\begin{tabular}{|c|l|l|l|}
\hline No. & \multicolumn{1}{|c|}{ variable } & \multicolumn{1}{|c|}{ Dassin } & \multicolumn{1}{c|}{ Das solein } \\
\hline 1. & Learning Method & Teacher Center Learning & Centred Learning \\
\hline 2. & learning process & Conventional(lecture model) & Interactive, cooperative, web-based \\
\hline 3. & Level of Understanding & Low Understanding & High understanding \\
\hline 4. & Student attitude & $\begin{array}{l}\text { Not enthusiastic, lazy, not } \\
\text { confident and not creative }\end{array}$ & $\begin{array}{l}\text { Enthusiastic, uplifting, confident and } \\
\text { creative }\end{array}$ \\
\hline 5. & $\begin{array}{l}\text { Examples of the } \\
\text { application of courses }\end{array}$ & $\begin{array}{l}\text { Examples, in general, are in } \\
\text { accordance with lecture material }\end{array}$ & $\begin{array}{l}\text { Special To the task of project } \\
\text { management information system } \\
\text { practice }\end{array}$ \\
\hline 6. & Final results/assessment & Learning outcomes & $\begin{array}{l}\text { The learning process and learning } \\
\text { outcomes }\end{array}$ \\
\hline
\end{tabular}

\subsection{ADDIE development}

Procedures of the development of this computer-based cooperative learning model can be described as follows:

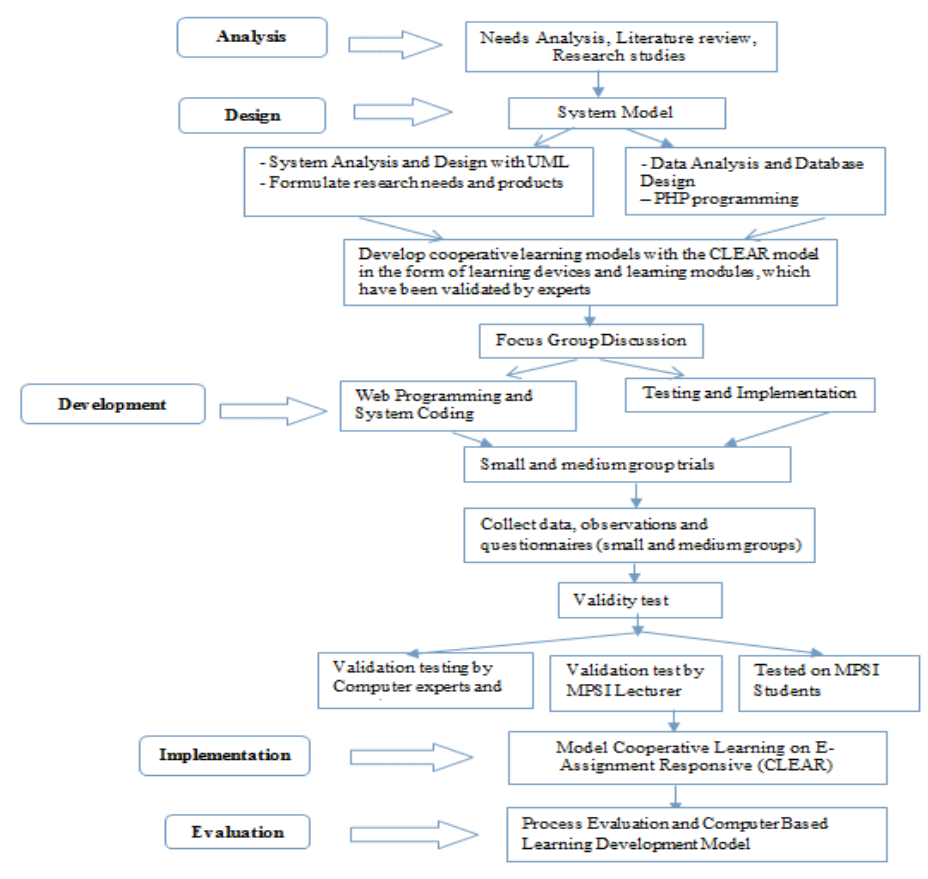

Fig. 1. Procedure Development Stages of computer-based Cooperative Learning models 
In the stage analyze identification of the causes of the gap between reality and what is expected from the learning is done. In the design phase verification of the form of the learning model that will be developed or desired and the appropriate test method. In the development stage, the activities carried out are to produce and validate the instruments and products that have been designed. In the phase, implementation learning is done with the model that has been developed. At the stage of an evaluation, of the process and product development is carried out.

\section{$4 \quad$ Results}

\subsection{Concept of the CLEAR model}

CLEAR Model is an information technology product that can be used for student lecturers to facilitate interaction in making student assignments presented on the website. All content, updates and activities are posted to this system and students can manage their interactions through messages, e-mail, and online forums. From the above statement, we can see the concept of CLEAR in Figure 2.

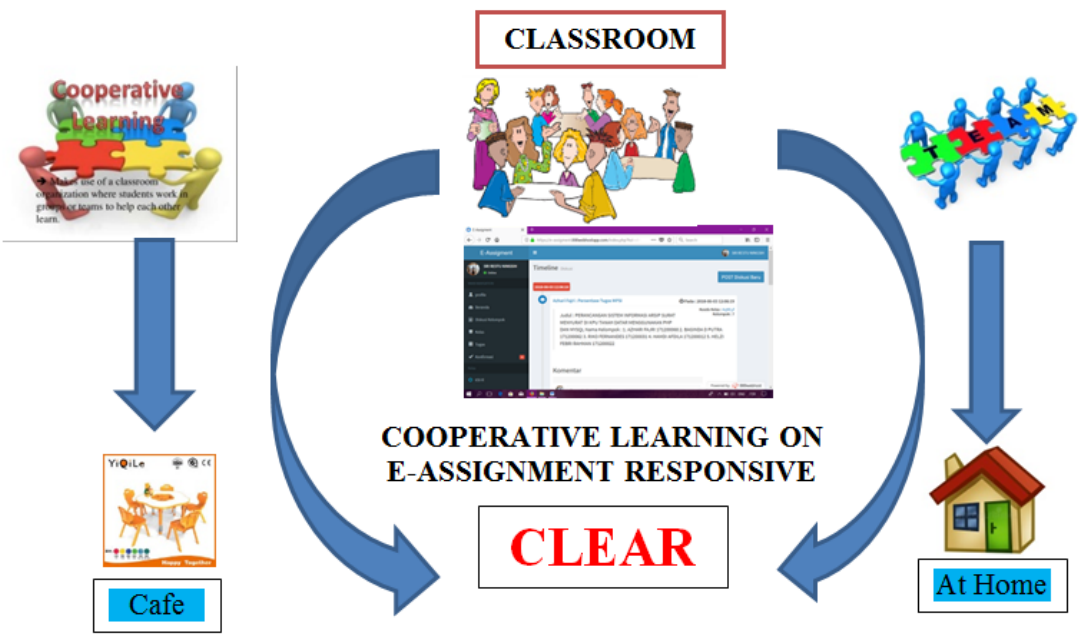

Fig. 2. Concept of CLEAR Model

Figure 2 explains that in this learning process the Lecturer uses a cooperative learning model in giving assignments to students. In a class, the Lecturer will divide students into several groups/teams consisting of 4-5 students to make group assignments given by the Lecturer. In developing this learning model, lecturers use the website for cooperative learning models, so that it will change the paradigm of conventional based learning models into web-based learning models.

In this case, student groups can conduct discussions about assignments given by lecturers through websites with logins as students. This group discussion can be done 
by students anywhere and anytime, such as at home, in the park, in cafes and wherever students are located. The time is free and unlimited in conducting group discussions via the web. However, the Lecturer still limits the time for collecting assignments for his students.

\subsection{Use Case Diagram}

Use Case Diagram describes the actors involved in the system along with the large activities (cases) that will occur in the system. In this information system, there are two users, namely lecturers and students. Lecturers are users who act as instructors who can create classes, accept students who join in their classes, give assignments, and give ratings and comments. While students are users who can register, join the class that the lecturer has made, collect assignments and comment. To find out what interactions are carried out between the user and this information system and what functions they can perform user lecturer can be seen in Figure 3.

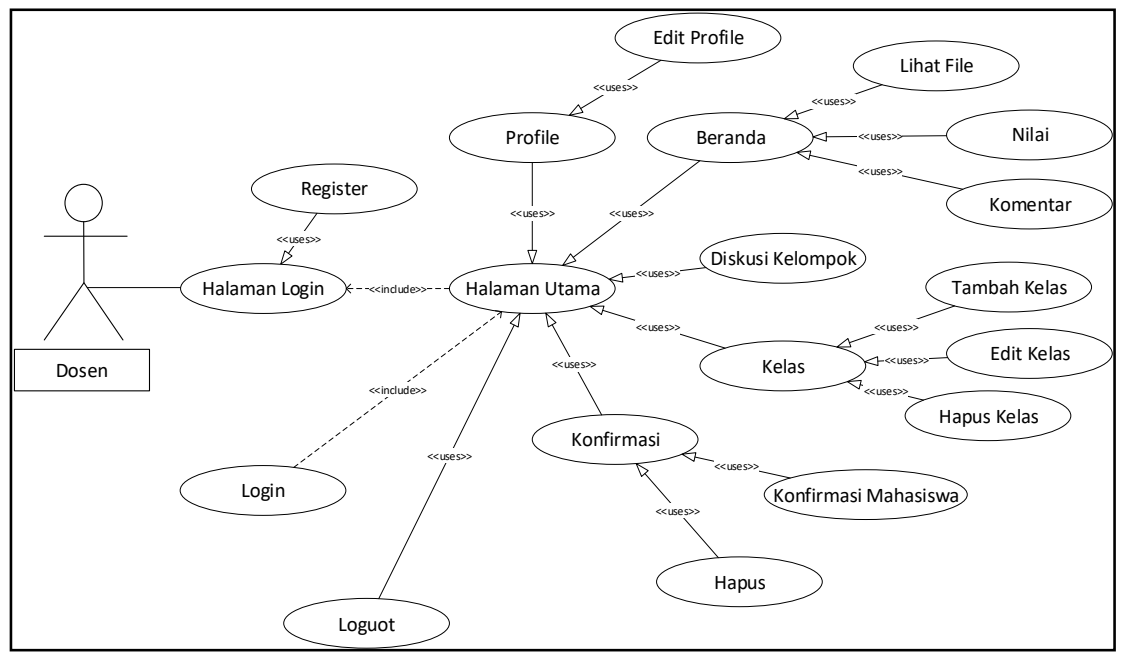

Fig. 3. Use Case Diagram Lecturer

From Figure 3, namely when the lecturer opens the login page, then on the page this login lecturer can register if you don't have an account to log in. After registering, the lecturer can log in, and select the menu available on the main page, such as profiles to view and edit profiles, home page to be able to see tasks, provide values and comments, classes to create new classes, edit classes and delete classes, confirmation to confirm students who will join the class that the lecturer has made and logout to exit the main page. For interactions and functions that can be performed by students can be shown in Figure 4. 


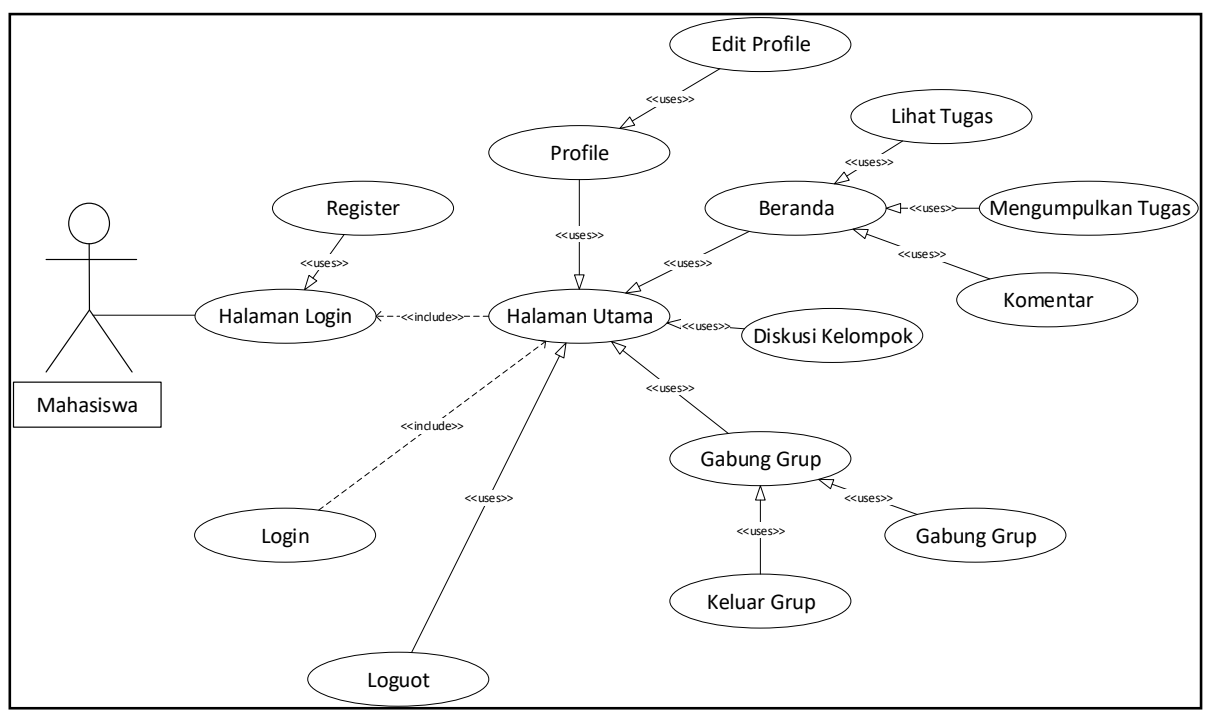

Fig. 4. Use Case Diagram Students

In Figure 4, students open a login page to be able to log in to the main page and if they don't have a login account, students can choose to register to create a login account. On the main page, students can choose the menu profile to view and edit profiles, the homepage to view, blunt tasks and comments, join groups to join groups and exit groups and logout to exit the main page.

\subsection{Class Diagram}

Class diagram: is a description of the structure and description of classes, packages, and interconnected objects such as inheritance, associations and others [12]. Class diagrams provide any information contained by each object. This information includes elements and elements included in system objects. The class diagram on this system is presented in Figure 5.

In this system, there are several classes and functions that can be performed by the user of this system. Some of these classes are the profile class for editing and viewing profiles, the homepage for performing assignments, comments, displaying who has collected assignments, see values and make judgments. Registration class to register to the system, class to add classes, edit classes, delete classes and search for classes. Task class, comment class, file view, assessment and task collection. 


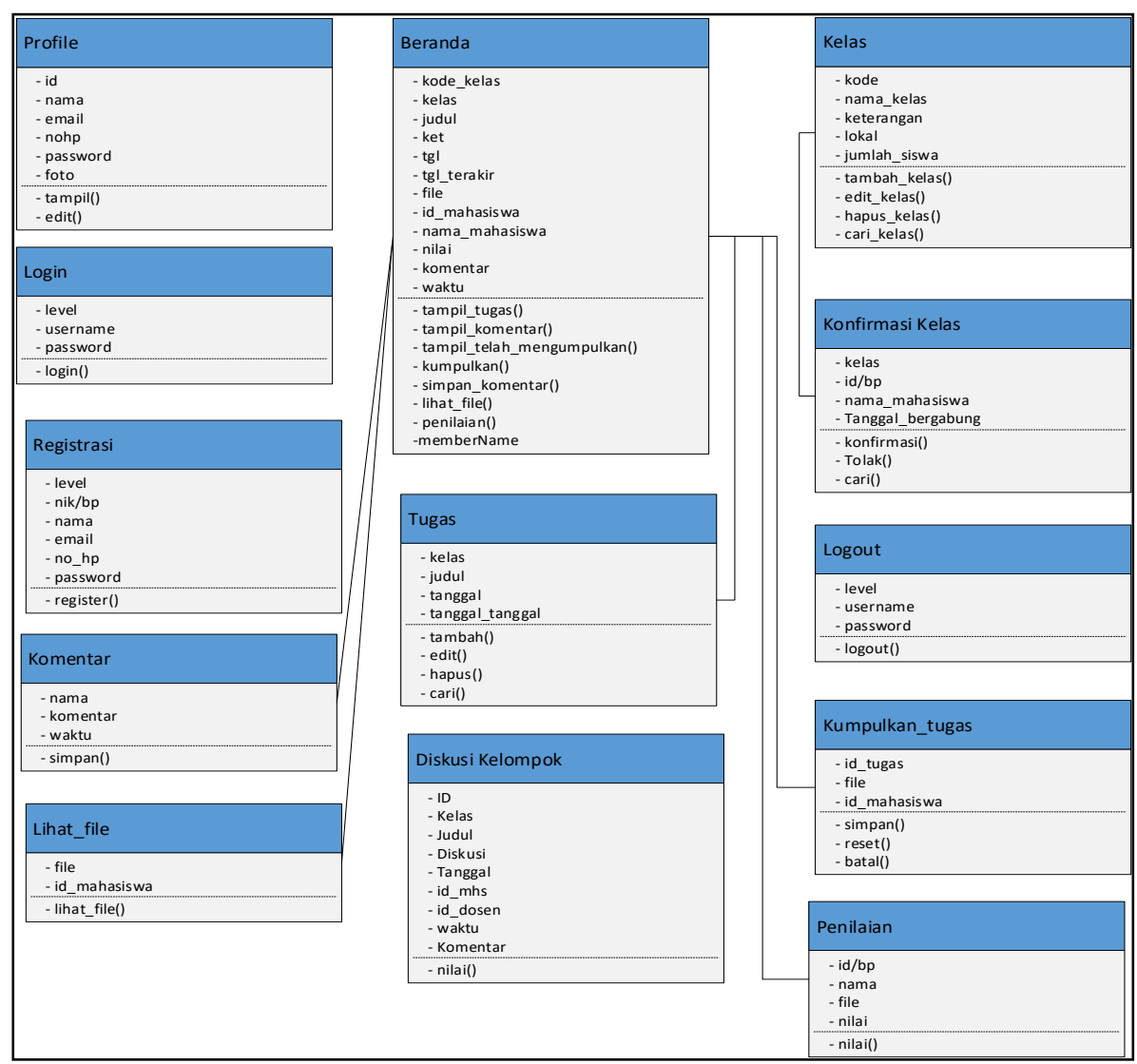

Fig. 5. Class Diagram

\subsection{Implementation system}

In order to log in and access this application, students must register or register first. As for how to register by opening the application and selecting "Register a new membership". After that, a registration form will appear to register a new user as a student. Students must fill in the data actually and after the data is filled in, just click the registration button, if the menu is complete, a menu will appear as shown in Figure 6. 


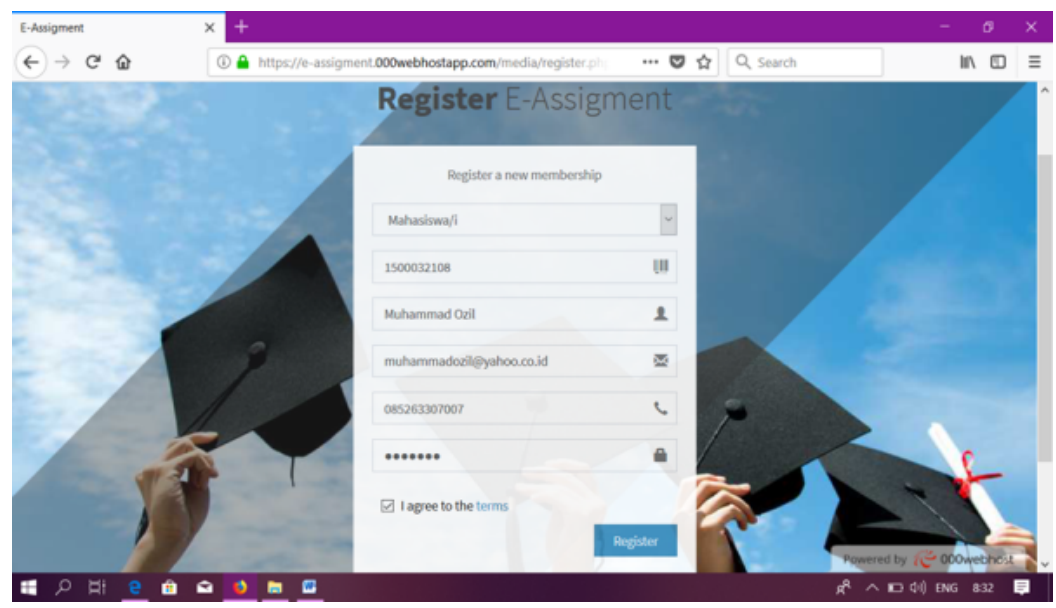

Fig. 6. Display of Register E-Assignment

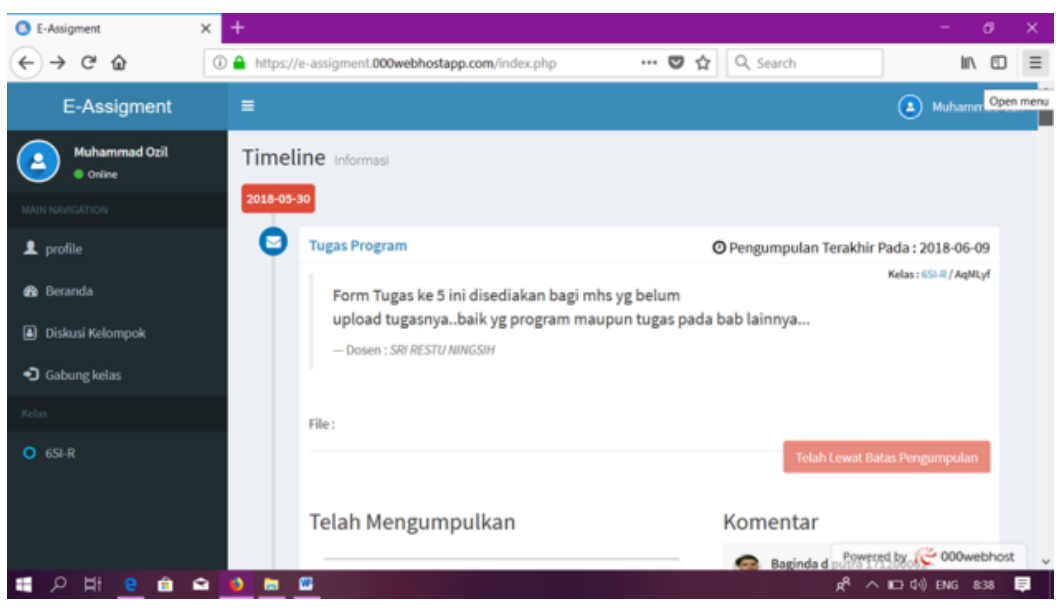

Fig. 7. Display of Home E-Assignment

In Figure 6, students must fill in every data in the register view, such as the choice of the student, NIM, name, email, cell phone number, and password. Students also have to click I agree to the terms, which is to agree to all applicable conditions. After that students can click Register if they have finished registering. After registering, it will return to the main menu to log in as a student.

In the Sign in to start your session view, students can log in by clicking Sign in. After logging in by clicking Sign In, the Home E-menu will appear Assignment as Figure 7.

As shown in Figure 7 shows the display of the E-Assignment homepage that displays the form of assignments given by the Lecturer. All tasks can be seen by all students who are logged in. 


\section{Conclusion}

The results of this study are a learning model in the form of a web-based student assignment application, with the name Cooperative Learning model on E-Assignment Responsive (CLEAR) that is applied in Higher Education. This model has been implemented in the Information Systems Project Management course, Information Systems Study Program at STMIK Indonesia Padang. But this model can also be used in all courses at the University. This CLEAR model can increase students' motivation to learn independently and creatively, in making assignments and can increase student grades.

\section{Acknowledgement}

On this occasion, we would like to thank the Amal Bakti Muslimin Foundation, STMIK Indonesia Padang, for providing financial support in writing this journal to completion, in accordance with contract number 038 / KA / LPPM / STMIK-I / 2019.

\section{$7 \quad$ References}

[1] L. Guo, Z. Zhao, L. Bai, and X. Zhao, "Design and Implementation of English Reading Examination System Based on WEB Introduction to Relevant Computer Technologies and System Platforms," International Journal of Emerging Technologies Learning (iJET), vol. 12, no. 12, pp. 45-56, 2017. https://doi.org/10.3991/ijet.v12.i12.7959

[2] H. Qu, "Application of Kinect Technology in Blind Aerobics Learning," International Journal of Emerging Technologies in Learning (iJET ), vol. 12, no. 12, 2017. https://doi. org/10.3991/ijet.v12.i12.7960

[3] C. Hursen, "Use of Gamification Applications in Science Education," International Journal of Emerging Technologies in Learning (iJET), pp .4-23, 2019. https://doi.org/10.3991/ ijet.v14i01.8894

[4] P. Juric, MB Bakaric, and M. Matetic, "Design and Implementation of Anonymized Social Network-based Mobile Game System for Learning Mathematics, " International Journal of Emerging Technologies in Learning (iJET), vol. 13, no. 12, pp. 83-98, 2018. https://doi. org/10.3991/ijet.v13i12.8762

[5] M. Chan and M. Zhang, "Architecture Design of Datacenter for Cloud English Education Platform," pp. 24-33, 2019. https://doi.org/10.3991/ijet.v14i01.9464

[6] EJ Gallardo-saborido, "Teaching to Training Teachers through Cooperative Learning," The 6th International Edu World Conference 2014 "Education Facing Contemporary World Issues ", 7th - 9th Teaching. January 2016. https: // doi: 10.1016 / j.sbspro.2015.02.136

[7] A. Pawattana, S. Prasarnpanich, and R. Attanawong, "Enhancing Primary School Students' Social Skills Using Cooperative Learning in Mathematics," Procedia - Soc. Behav. Sci., vol. 112, no. Iceepsy 2013, pp. 656-661, 2014. https: // doi: 10.1016 / j.sbspro.2014.01.12 $\underline{14}$

[8] X. Chen, "Design and Implementation of the University of Art Education Management System Based on JAVA Technology," vol. 13, no. 10, pp. 83-94, 2018. 
[9] VD Tran, A.Giang, and A.Giang, "The Effects of Cooperative Learning on the Academic Achievement and Knowledge Retention," vol. 3, no. 2, pp. 131-140, 2014. http://dx.doi. org/10.5430/ijhe.v3n2p131

[10] LH Leng, CH Leng, and N. Abedalaziz, "Using Cooperative Learning Weblogs to Improve the Achievement of History Learning," Malaysian Online J. Educ. Technol., vol. 1, no. 3, pp. 30-43, 2013.

[11] İ. Ü. Yapici, "Effectiveness of Blended Cooperative Learning Environment in Biology Teaching: Classroom Community Sense, Academic Achievement and Satisfaction," vol. 4, no. 4, pp. 269-280, 2016. http://dx.doi.org/10.11114/jets.v4i4.1372

[12] M Teguh Prihandoyo, "Unified Modeling Language (UML) Model for Developing WebBased Academic Information Systems," J. Inform. J. Development IT, vol. 3, no. 1, pp. 126-129, 2018.

\section{Authors}

Sri Restu Ningsih is a Lecturer at STMIK Indonesia Padang with Information Systems Study Program. Currently attending the Doctoral Program at the Faculty of Engineering, Padang State University by taking a major in Technology and Vocational Education (email: srirestuningsih@, stmikindonesia.ac.id).

Z. Mawardi Effendi. is a Professor at Padang State University. He is a Postgraduate Lecturer at the Faculty of Economics, Padang State University (email: zmeffendi@gmail.com).

Nurhasan Syah is a Doctor of Education who teaches at the Faculty of Civil Engineering and Postgraduate Faculty of Engineering at Padang State University, (email: nurhasan_s@yahoo.com).

Article submitted 2019-04-27. Resubmitted 2019-07-16. Final acceptance 2019-07-19. Final version published as submitted by the authors. 